University of Nebraska - Lincoln

DigitalCommons@University of Nebraska - Lincoln

\title{
Biotic Interactions as Determinants of Ecosystem Structure in Prairie Wetlands: An Example Using Fish
}

\author{
Mark A. Hanson \\ Minnesota Department of Natural Resources, mark.hanson@dnr.state.mn.us \\ Kyle D. Zimmer \\ University of St. Thomas, Minnesota \\ Malcolm G. Butler \\ North Dakota State University - Main Campus \\ Brian A. Tangen \\ U.S. Geological Survey, btangen@usgs.gov \\ Brian R. Herwig \\ Minnesota Department of Natural Resources \\ See next page for additional authors
}

Follow this and additional works at: https://digitalcommons.unl.edu/usgsnpwrc

Hanson, Mark A.; Zimmer, Kyle D.; Butler, Malcolm G.; Tangen, Brian A.; Herwig, Brian R.; and Euliss, Ned H. Jr., "Biotic Interactions as Determinants of Ecosystem Structure in Prairie Wetlands: An Example Using Fish" (2005). USGS Northern Prairie Wildlife Research Center. 270.

https://digitalcommons.unl.edu/usgsnpwrc/270

This Article is brought to you for free and open access by the US Geological Survey at DigitalCommons@University of Nebraska - Lincoln. It has been accepted for inclusion in USGS Northern Prairie Wildlife Research Center by an authorized administrator of DigitalCommons@University of Nebraska - Lincoln. 


\section{Authors}

Mark A. Hanson, Kyle D. Zimmer, Malcolm G. Butler, Brian A. Tangen, Brian R. Herwig, and Ned H. Euliss Jr. 


\title{
BIOTIC INTERACTIONS AS DETERMINANTS OF ECOSYSTEM STRUCTURE IN PRAIRIE WETLANDS: AN EXAMPLE USING FISH
}

\author{
Mark A. Hanson ${ }^{1,2}$, Kyle D. Zimmer ${ }^{2,3}$, Malcolm G. Butler ${ }^{2}$, Brian A. Tangen ${ }^{2,4}$, Brian R. Herwig, and \\ Ned H. Euliss, Jr. ${ }^{6}$ \\ ${ }^{1}$ Wetland Wildlife Populations \& Research Group \\ Minnesota Department of Natural Resources \\ $10223^{\text {rd }}$ St. NE \\ Bemidji, Minnesota, USA 56601 \\ E-mail:mark.hanson@dnr.state.mn.us \\ ${ }^{2}$ Department of Biological Sciences \\ North Dakota State University \\ Fargo, North Dakota, USA 58105 \\ ${ }^{3}$ Present address: Department of Biology \\ University of St. Thomas \\ 2115 Summit Avenue \\ St. Paul, Minnesota, USA 55105 \\ ${ }^{4}$ Present address: U.S. Geological Survey \\ Biological Resources Division \\ Northern Prairie Wildlife Research Center \\ $871137^{\text {th }}$ St. SE, Jamestown \\ North Dakota, USA 58401 \\ ${ }^{5}$ Minnesota Department of Natural Resources \\ 2114 Bemidji Avenue \\ Bemidji, Minnesota, USA 56601 \\ ${ }^{6}$ U.S. Geological Survey \\ Biological Resources Division \\ Northern Prairie Wildlife Research Center \\ 8711 37th St. SE \\ Jamestown, North Dakota, USA 58401
}

\begin{abstract}
Wetlands are abundant throughout the prairie pothole region (PPR), an area comprising over $700,000 \mathrm{~km}^{2}$ in central North America. Prairie wetland communities are strongly influenced by regional physiography and climate, resulting in extreme spatial and temporal variability relative to other aquatic ecosystems. Given the strong influence of abiotic factors, PPR wetland communities have been viewed traditionally in the context of their responses to chemical and physical features of landscape and climate. Although useful, this physical-chemical paradigm may fail to account for ecosystem variability due to biotic influences, particularly those associated with presence of fish. Spatial and temporal variability in fish populations, in turn, may reflect anthropogenic activities, landscape characteristics, and climate-mediated effects on water levels, surface connectivity, and hydroperiods. We reviewed studies assessing influences of fish on prairie wetlands and examined precipitation patterns and biological data from PPR wetlands in east-central North Dakota and western Minnesota, USA. Our review and analysis indicated that native fish influence many characteristics of permanently flooded prairie wetlands, including water clarity and abundance of phytoplankton, submerged macrophytes, and aquatic invertebrates. We suggest that ecologists and managers will benefit from conceptual paradigms that better meld biotic interactions associated with fish, and perhaps other organisms, with chemical and physical influences on prairie wetland communities.
\end{abstract}

Key Words: prairie wetlands, biotic interactions, abiotic influences, aquatic invertebrates, fathead minnows, predation, community structure 


\section{INTRODUCTION}

The prairie pothole region (PPR) of North America comprises an area of more than $700,000 \mathrm{~km}^{2}$ throughout the central United States and Canada (Luoma 1985, Kantrud et al. 1989a). Across this region, interactions among glacial history, geology, and climate resulted in moraines and outwash plains dotted with vast numbers of water-filled depressions known as prairie wetlands or potholes (Kantrud et al. 1989a, Winter 1989). These wetlands vary widely in physical and chemical features, largely due to local topography, interactions with ground water, and annual precipitation. Precipitation is the predominant water source for prairie wetlands due to low permeability of underlying glacial till, and evapotranspiration contributes most to annual water loss (Winter and Rosenberry 1998).

The PPR is influenced by a variety of air masses due to its central location within the North American continent (LaBaugh et al. 1996, 1998, Winter and Rosenberry 1998). Climatic extremes are typical, and temperatures range from $40^{\circ} \mathrm{C}$ during summer to $-40^{\circ} \mathrm{C}$ in winter. Dry, polar air often predominates during winter; a summer influence of warm, dry air masses from continental desert regions is intermittent, yet important. Interactions among these air masses contribute to a highly variable balance between precipitation and evapotranspiration and are largely responsible for regulating regional water availability. Annual precipitation:evapotranspiration (P:E) ratios across the region typically are $<1.0$ (Winter 1989, Winter and Rosenberry 1998). However, P:E ratios increase along west-to-east and north-to-south gradients (Winter 1989, Winter and Rosenberry 1998, Euliss et al. 1999), and annual ratios may approach 1.0 near the eastern margin of the PPR (MDNR 2001). Regional precipitation extremes influence not only spatial and temporal variation in wetland hydroperiods and depths (Johnson et al. 2004), but also induce chemical and physical variability among basins (Euliss et al. 2004).

Prairie wetlands support diverse communities of hydrophytes, mammals, amphibians, birds, and aquatic invertebrates adapted to these harsh but productive environments (Kantrud et al. 1989a,b, Swanson and Duebbert 1989, Euliss et al. 1999). These wetland communities are strongly influenced by abiotic features (Kantrud et al. 1989a,b, Murkin 1989, Euliss et al. 1999) and, not surprisingly, are usually interpreted as localized responses to climate, geology, and interactions with ground water (Winter 1989, Euliss et al. 1999). Evidence is strong for the importance of abiotic constraints on characteristics and communities of PPR wetlands, and the wetland continuum concept sug- gested by Euliss et al. (2004) is largely based on these relationships.

Research to clarify ecosystem-level influences of species interactions in prairie wetlands has lagged behind efforts in other aquatic ecosystems, in part because abiotic constraints often have such obvious consequences for wetland communities. However, functional roles of planktivorous and piscivorous fishes in prairie wetlands recently have been assessed, and where fish occur, they exert strong influences (Hanson and Riggs 1995, Zimmer et al. 2000, 2001a, 2002, 2003b, Herwig et al. 2004) similar to those reported for fishes in other shallow ecosystems (Hŕbáček 1961, Hanson and Butler 1994, Jeppesen et al. 1997, Scheffer 1998, and many others). Wellborn et al. (1996) suggested that interplay between biotic and abiotic influences constrain aquatic communities in a predictable manner along gradients of habitat permanence. However, relative comparisons of biotic and abiotic factors as constraints on characteristics of prairie wetlands are notably absent from the literature. Such assessments are needed for better understanding of roles of species interactions in structuring wetland communities, to account for observed spatial and temporal variability, and to refine wetland management strategies.

It seems likely that influences of species interactions will vary in predictable ways across gradients of wetland characteristics and climate. For example, presence of fish in surface waters is a probability function influenced by likelihood of colonization and extinction, events linked to surface connectivity and climatic variability (Tonn and Magnuson 1982, Rahel 1984, Magnuson et al. 1998). Because precipitation extremes throughout the PPR induce fluctuations in wetland depth, hydroperiod characteristics, and surface connectivity (Leibowitz and Vining 2002, Johnson et al. 2004), moisture dynamics have potential to modify distribution and ecological influences of fish, thus affecting magnitude of biotic constraints on wetland communities.

We assessed relative magnitude of selected biotic and abiotic influences on several features of semipermanent prairie wetlands. Using direct gradient analysis, we compared performance of several simple models to contrast influences of fish presence/absence (as a proxy for species interactions) and specific conductance (as a proxy for abiotic constraints) on invertebrate communities and water-quality features. We also reviewed long-term precipitation dynamics along the eastern margins of the PPR to illustrate how moisture patterns here may induce variation in the strength of biotic interactions among wetlands and over time. 


\section{METHODS}

Assessing Biotic and Abiotic Influences at a Regional Scale: Community Analyses

Field Methods. We used data from two field studies of semi-permanent (North Dakota sites) and permanent (Minnesota sites) prairie wetlands (following classification of Stewart and Kantrud 1971) to assess relative importance of fish presence/absence and specific conductance on aquatic invertebrates and water quality. We used specific conductance as a proxy measure to reflect sources of abiotic variability among our study sites. This is possible because concentrations of chemical constituents strongly reflect influences of ground water, topography, and thus landscape setting in northern prairie wetlands (Winter and Woo 1990). In the PPR, surface-water chemistry integrates influences of local ground water, geology, topography, and annual $\mathrm{P}: \mathrm{E}$ ratios. Low ionic concentrations reflect influences of surface-water discharge to underlying ground water, along with loss of dissolved constituents. Alternatively, wetlands with a predominant flux of water from ground water into the wetland basin accumulate dissolved constituents, and this is accentuated by evaporation of surface water. Relationships among ionic concentrations in prairie wetlands, interactions with ground water and local geology, and other landscape features are well-known, highly predictable, and support our generalized application here (Arndt and Richardson 1988, Swanson et al. 1988, Richardson and Arndt 1989, Winter and Woo 1990, LaBaugh et al. 1998).

In our first study, data on catch per unit effort of wetland fish, abundance of zooplankton and macroinvertebrates, turbidity, phytoplankton abundance (chlorophyll $a$ ), specific conductance, and concentrations of total phosphorus and nitrogen in the water column were gathered during 1998-1999 from 19 wetlands along the eastern margin of the PPR in west-central Minnesota (MN sites). In a second study, similar data were collected during 2000 from 23 wetlands in eastcentral North Dakota (ND sites) (Figure 1). The MN and ND sites were distributed across an area of approximately $3,751 \mathrm{~km}^{2}$ and $23,400 \mathrm{~km}^{2}$, respectively. Most MN sites were located on Waterfowl Production Areas owned and managed by the U.S. Fish and Wildlife Service and were adjacent to uplands vegetated largely by grasses. ND sites were located on private land and were adjacent to uplands with more variable vegetation cover types ranging from agricultural crops to native grasses.

Sampling was done each year during May-August, and samples were gathered along random transects within each study wetland. At MN sites, fish abundance was assessed using modified Gee-type minnow

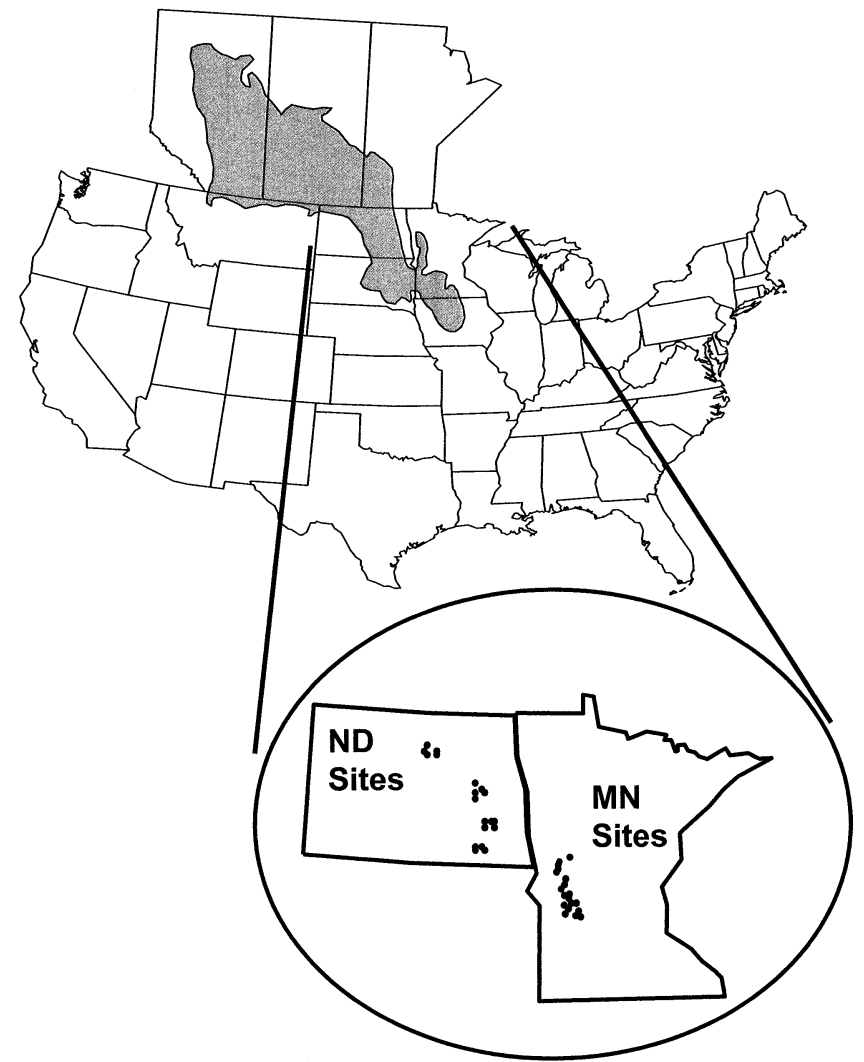

Figure 1. Approximate location of the study wetlands in Minnesota and North Dakota, USA and their location within the Prairie Pothole Region (grey area above).

traps during May, July, and August each year. Fish were collected using tube-shaped traps (after Hubert 1983) during June and August in ND sites. During each sampling at MN sites, we recorded biomass of all fish captured in five traps. We subsequently calculated seasonal means for each wetland based on data gathered during the three sampling efforts. At ND sites, fish abundance was estimated by volume, and species were calculated as $\%$ of total catch. Fathead minnows (Pimephales promelas Rafinesque) were the predominant fish species in all study wetlands, although brook sticklebacks (Culea inconstans Kirkland), central mudminnows (Umbra limi Kirtland), and other species were captured occasionally. Because these other species generally contributed $<1.0 \%$ of the total fish biomass in our study sites, we attribute all significant fish effects to fathead minnows. Although we recorded relative abundance of fish in our study sites, we treated fish as a categorical variable (present/ absent) in our analyses. Nine of the $19 \mathrm{MN}$ sites and 17 of the 23 ND sites were fishless during our study.

We sampled aquatic invertebrates in the MN sites six times per year (1998-1999), every third week from May through August. Invertebrates in the ND sites were sampled in mid-June, mid-July, and mid-August 
2000. In all sites, macroinvertebrates were sampled along random transects using activity traps (ATs) after designs of Murkin et al. (1983). Ten AT samples were collected from each wetland on each sampling date, and samples were condensed by passage through a $330-\mu \mathrm{m}$ concentrating funnel. Zooplankton were sampled concurrently with AT samples in the MN sites using a vertical-column sampler described by Swanson (1978). Five column samples were taken from each wetland on each date and were concentrated using a $68-\mu \mathrm{m}-\mathrm{mesh}$ funnel. Column samples were not collected from the ND sites; thus, the final data sets from MN sites consisted of both macroinvertebrates (AT samples) and zooplankton (column samples), while the ND data included macroinvertebrates only. All invertebrate samples were preserved in $70 \%$ ethanol. In the lab, invertebrates were identified using keys by Pennak (1989) and Merritt and Cummins (1996). Taxonomic resolution varied between samples collected from MN and ND sites, but identification was made to order, suborder, family, or genus. Number of invertebrates in each taxon was totaled for each wetland on each sampling date based on ten AT and five column samples in the MN sites and the ten AT samples in the ND sites. Seasonal means for each taxon were calculated from the six sampling dates in MN sites and used for analyses. Mean values for each sampling date were used in analyses of data from the ND sites.

Water samples were taken from the center of each wetland on the same dates we sampled aquatic invertebrates in all sites and were analyzed for total phosphorus, total nitrogen, and chlorophyll $a$. Samples from MN and ND sites were analyzed by the Minnesota Department of Agriculture Chemistry Laboratory and the North Dakota Department of Health Laboratory, respectively, according to APHA (1992). Turbidity and specific conductance were measured in the field concurrently with collection of water samples using a LaMotte portable nephelometer (model 2020) and a YSI specific conductance meter (model 58).

Statistical Analyses of Field Data. Data from MN and ND sites were analyzed separately due to differences in study designs and data collection protocols. We used redundancy analysis (RDA), the linear form of direct gradient analysis (ter Braak 1995, Van Wijngaarden et al. 1995), to assess influences of fish presence/absence and specific conductance on aquatic invertebrate communities and water quality characteristics of our study wetlands. We chose RDA because preliminary ordinations with detrended correspondence analysis showed that gradient lengths were all $<2.0$ standard deviations (indicating a linear response model was appropriate, Van Wijngaarden et al. 1995) and because we focused on relationships between community structure and environmental variables (McCune and Grace 2002). Our environmental data consisted of presence/absence of fish (a categorical variable) and specific conductance (a continuous variable). Similar to multiple regression, categorical and continuous predictor (environmental) variables may be used simultaneously in RDA (ter Braak 1995). For both MN and ND water-quality data sets, dependent variables consisted of total phosphorus, total nitrogen, chlorophyll $a$, molar ratios of total nitrogen:total phosphorus, and turbidity. Invertebrate data sets consisted of numbers of organisms in 31 and 49 taxa in samples from the MN and ND sites, respectively. For MN sites, seasonal means of water-quality variables, abundance counts of each taxon, and specific conductance of each wetland were used in statistical analysis. In ND sites, we used values of each of these same variables, except that we averaged data for each of the three sampling dates prior to analysis. Thus, time was treated as a two-level covariable in the MN data (years, 19981999) and a three-level covariable in the ND data (months, June-August). All invertebrate and waterquality data were $\ln (n+1)$-transformed prior to analysis to equalize variance among the response variables (ter Braak 1995, Van Wijngaarden et al. 1995).

We used variance partitioning to assess the relative importance of specific conductance and fish presence/ absence on the invertebrate communities and waterquality characteristics of both MN and ND sites. This was done using partial RDA (pRDA, ter Braak and Wiertz 1994), where either presence/absence of fish or specific conductance was treated as an explanatory variable, while the alternative variable and time were treated as covariables. This allowed us to evaluate the "pure" effect of each variable and to assess the statistical significance of variance contributed by each using Monte Carlo tests (based on 1,000 permutations). To evaluate further the variance explained, we also modeled (pRDA) the same responses using both fish and specific conductance as explanatory variables with time as a covariable. Because three significance tests were applied to each data set, we used a sequential Bonferroni correction to maintain an experiment-wise error rate of $\mathrm{P}<0.05$ (Rice 1990). We show results of pRDA with presence/absence of fish and specific conductance as explanatory variables and time as a covariable. All analyses on the field data were performed using CANOCO 4.0 (ter Braak and Smilauer 1998).

\section{Analysis of Regional Moisture Patterns}

We assessed temporal trends in water availability along the eastern extent of the PPR using cluster analysis based on four historical measures; the Palmer 
Drought Severity Index (Palmer 1965), regional precipitation totals, localized precipitation totals, and annual peak discharge of the Red River. Regional-scale annual precipitation totals and Palmer Drought Severity Index values (PDSI) from western Minnesota during 1895-2000 were obtained from the National Climatic Data Center (NCDC; Minnesota Division I, Asheville, North Carolina and the Minnesota Department of Natural Resources [MDNR], Division of Waters, St. Paul, Minnesota). PDSI integrates precipitation, evapotransporation, and soil-moisture characteristics; thus, it better reflects moisture conditions at the landscape surface than do annual precipitation summaries alone. To supplement regional precipitation data, we used annual precipitation totals (1950-2000) from a site near Fergus Falls, Minnesota, an area centrally located within Minnesota's PPR and recognized for its high concentration of prairie wetlands (MDNR, Division of Waters, St. Paul, Minnesota). We also examined annual peak-discharge data $(1882,1897$, 1899-2000) from the Red River at Fargo, North Dakota (U.S. Geological Survey, Historical Streamflow database). The Red River is a major regional watercourse draining an area of approximately $10,944 \mathrm{~km}^{2}$ along the eastern portion of the PPR.

Clusters were established using a data matrix comprised of four moisture indicators, including regional annual precipitation totals and mean annual PDSI, annual precipitation totals from Fergus Falls, and annual peak discharge of the Red River. We restricted this statistical analysis to the period of 1950-2000 because continuous data for all four moisture characteristics were available only from 1950-present. All data were relativized by the maximum prior to analysis to control for different measurement scales. Our analysis was performed using Euclidean distance and the flexiblebeta group linkage method (beta $=-0.25$; Ludwig and Reynolds 1988). We tested statistical significance of combinations of years using multiple response permutation procedures (MRPP) (Biondini et al. 1988). Because P-values associated with MRPP tests are based on data-dependent permutation procedures, significance tests have no requirements for underlying data distributions. Cluster analyses were performed using PC-ORD (McCune and Medford 1999). Precipitation totals, PDSI, and peak discharge data were also assessed graphically.

\section{RESULTS}

Biotic Influences-Community Analyses

Independent analyses using data from MN and ND sites indicated that presence/absence of fathead minnows (fish) was associated with significant variance in

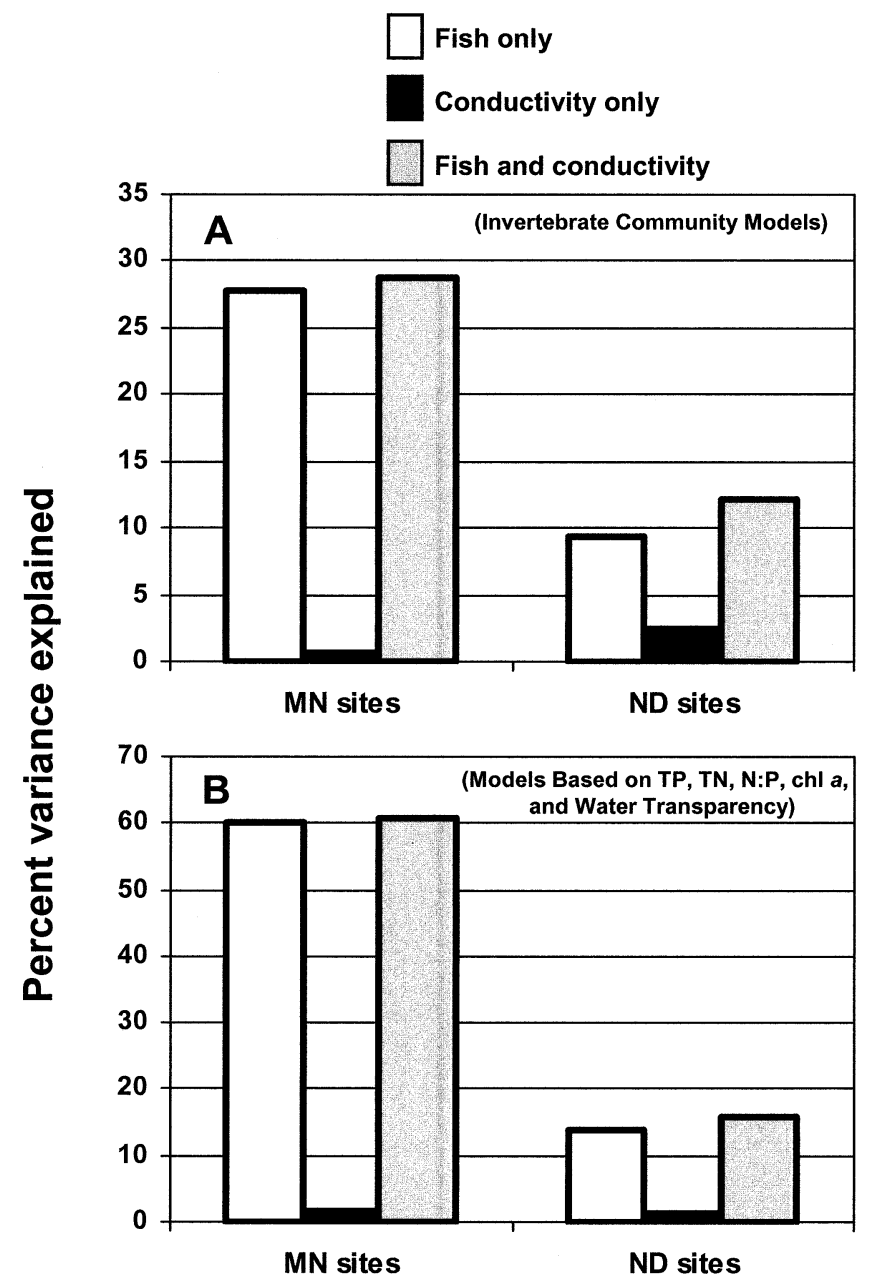

Figure 2. Percent variance explained in the invertebrate data (panel A) and water-quality data (panel B) by three partial redundancy analysis models. Model parameters were as follows: fish presence/absence as main effect (time, specific conductance as covariables); specific conductance as main effect (time, fish presence/absence as covariables); fish and specific conductance as main effects (time as covariable).

wetland characteristics. For MN sites, our pRDA model using both fish and specific conductance as explanatory variables and time as a covariable (full models) explained the most variance $(28.7 \%)$ in the structure of aquatic invertebrate communities $(\mathrm{P}=0.003)$. Reduced invertebrate models indicated that fish alone $(\mathrm{P}$ $=0.003$ ) explained approximately 46 times more variance in invertebrate communities than conductivity alone, and the latter model was not significant $(\mathrm{P}=$ 0.990, Figure 2A). Thus, most of the variance accounted for by our full model was associated with fish. Similar, but weaker, trends were obtained from modeling ND invertebrate data. Our full invertebrate model for ND sites explained $12.0 \%$ of the variance in these communities $(\mathrm{P}=0.003)$. Reduced ND models 


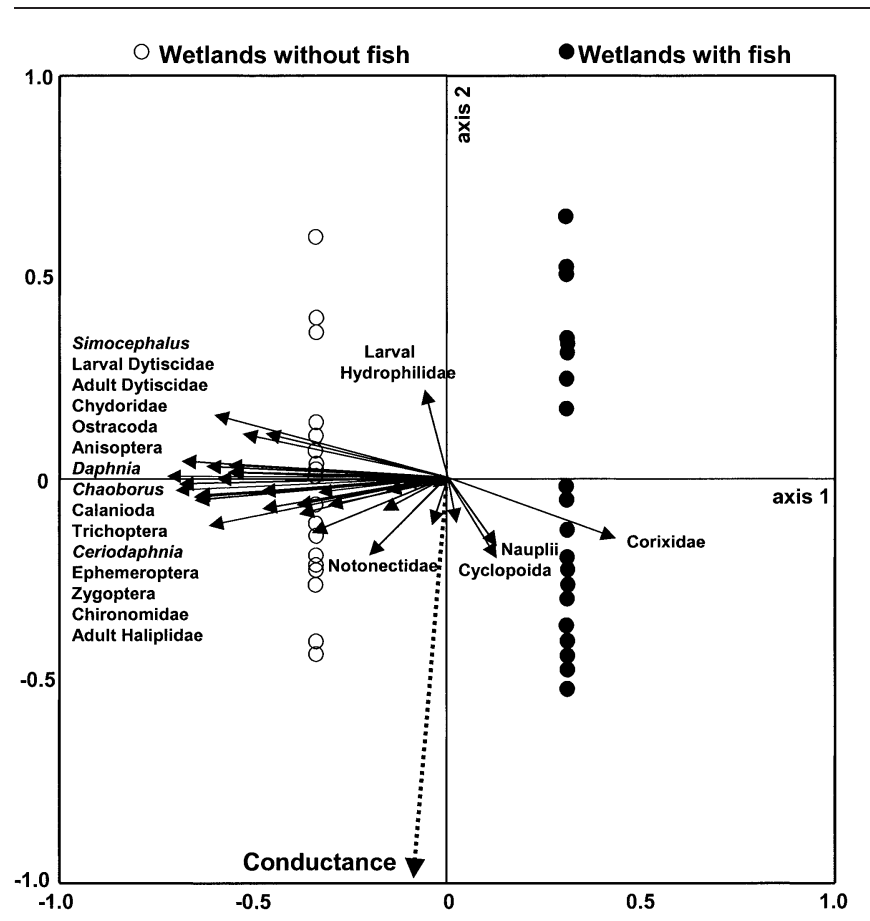

Figure 3. Partial redundancy analysis triplot for the invertebrate data from MN sites based on fish (presence/absence) and specific conductance as explanatory variables and time as a covariable. Species vectors and the specific conductance vector point in the direction of increasing values among sites. Axis 1 and 2 explained $28.1 \%$ and $0.6 \%$ of the variance in invertebrate communities, respectively.

showed that fish alone $(\mathrm{P}=0.003)$ explained four times the variance relative to specific conductance alone $(\mathrm{P}=0.010$, Figure $2 \mathrm{~A})$.

RDA plots showed that most aquatic invertebrate taxa we assessed were less abundant in wetlands with minnows, and this trend was evident in data from both studies (Figure 3,4). Major groups of crustaceans and aquatic insects, including Ceriodaphnia, Daphnia, Simocephalus, Chydoridae, Calanoida, Odonata, Trichoptera, Ephemeroptera, Chironomidae, and Chaoborus, were less abundant where minnows were present. Not all invertebrate taxa showed strong negative association with fish. For example, weak, negative associations between fish and Hydrophilidae, Notonectidae, Hydracarina, Hirudinea, and Physidae were evident in MN sites, while nauplii and Cyclopoida were more abundant in MN sites with fish (Figure 3). Corixidae (Tricorixa and Sigara in ND sites) were usually far more abundant in wetlands with minnows in wetlands of both states (Figure 3,4). In both MN and ND sites, correlations with specific conductance were more muted than those we observed with fish. In MN sites, Notonectidae and Cyclopoida were positively associated and Hydrophilidae were negatively associated with increasing specific conductance (Figure 3). In ND

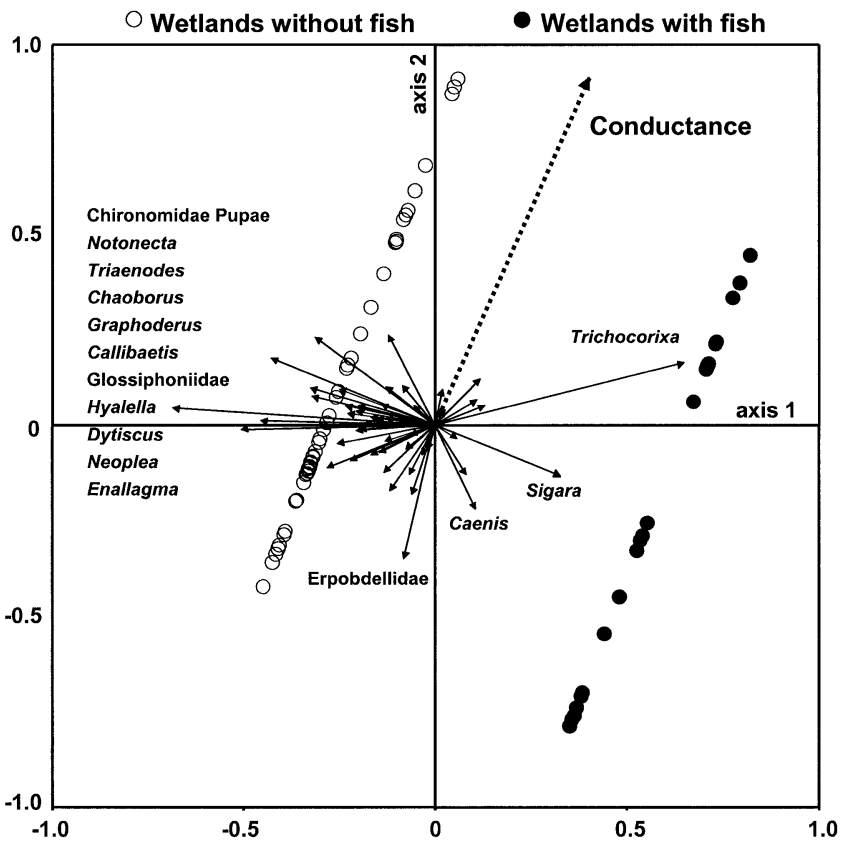

Figure 4. Partial redundancy analysis triplot for invertebrate data from ND sites based on fish (presence/absence) and specific conductance as explanatory variables and time as a covariable. Species vectors and the specific conductance vector point in the direction of increasing values among sites. Axis 1 and axis 2 explained $12.0 \%$ and $1.2 \%$ of the variance in the invertebrate communities, respectively.

sites, Erpobdellidae were negatively associated with increasing specific conductance (Figure 4).

Water-column concentrations of TP, TN, chlorophyll $a$, water transparency, and $\mathrm{N}: \mathrm{P}$ ratios for $\mathrm{MN}$ and ND sites also were best explained by models including fish presence/absence. Our MN water-quality model using both fish and specific conductance explained the most variance $(60.9 \%)$ in this suite of variables $(\mathrm{P}=0.003)$. Comparison of reduced $\mathrm{MN}$ waterquality models (fish only, $\mathrm{P}=0.003$ and specific conductance only, $\mathrm{P}=0.308$ ) indicated that our fish-only model explained approximately 38 times more variance in water-quality characteristics than did our model using only specific conductance (Figure 2B). Thus, as with the MN invertebrate data, nearly all the waterquality variance explained was contributed by fish. For ND sites, water-quality variance explained by fish and specific conductance was much lower than with MN data. ND models including both fish and specific conductance explained the most variance $(15.7 \%)$ in water-quality parameters $(\mathrm{P}=0.003)$. Reduced waterquality models for ND sites indicated that the fish-only model $(\mathrm{P}=0.003)$ explained approximately 13 times more variance in water-quality characteristics than did our model using only specific conductance $(\mathrm{P}=0.308$, Figure 2B). RDA plots showed that presence of fish 


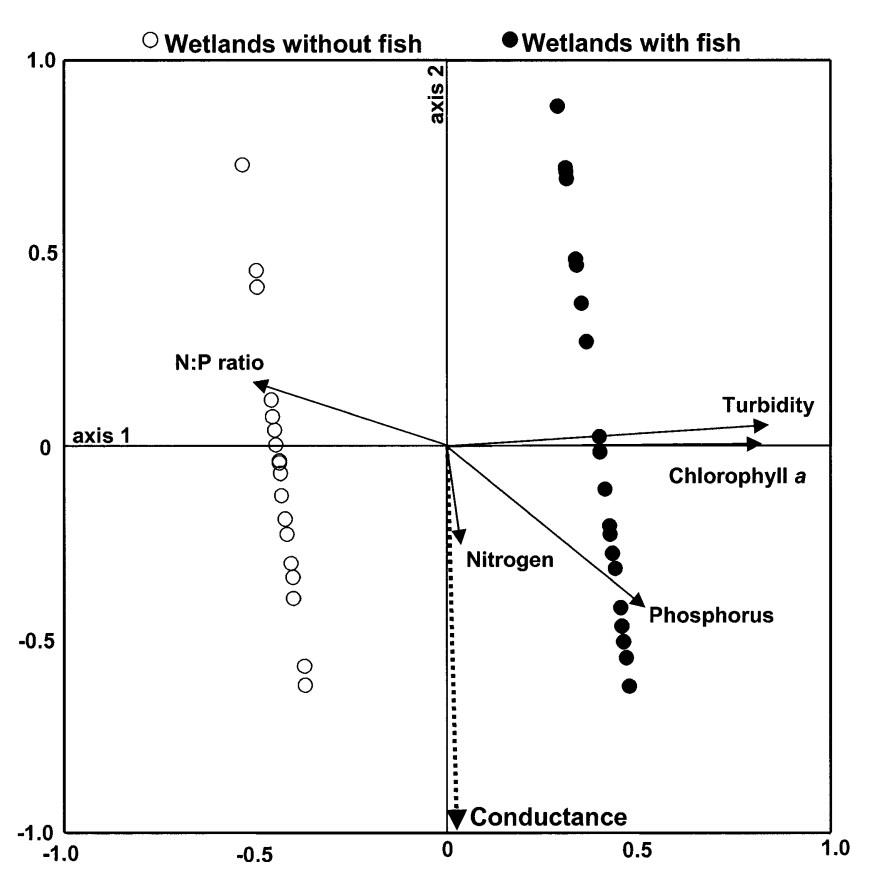

Figure 5. Partial redundancy analysis triplot for waterquality data from MN sites based on fish (presence/absence) and specific conductance as explanatory variables and time as a covariable. Water quality vectors and the specific conductance vector point in the direction of increasing values among sites. Axis 1 and 2 explained $60.3 \%$ and $0.7 \%$ of the variance in water-quality characteristics, respectively.

was strongly associated with elevated water-column chlorophyll $a$ and turbidity in MN sites (Figure 5) and with increasing chlorophyll $a$ in ND sites (Figure 6). Furthermore, N:P ratios were negatively associated with fish presence in MN sites (Figure 5). In general, other associations between specific conductance and water-quality characteristics were less evident in our data from either MN or ND.

\section{Regional Precipitation Patterns}

Several lines of evidence indicated that landscape moisture levels were consistently elevated along the eastern margin of the PPR during the final decade of the $20^{\text {th }}$ century. Regional (NCDC Minnesota Division I) annual precipitation totals, along with PDSI values, reflect a precipitation pulse during 1991-2000; this was rivaled only by levels recorded from 1895-1909 (Figure 7A,C). Annual precipitation data from Fergus Falls, Minnesota indicated that, since 1950, 19892000 was the longest consecutive period during which annual precipitation exceeded $50 \mathrm{~cm}$ (Figure 7B). At Fergus Falls, annual precipitation totals exceeded 60 cm during 1996-2000. Peak annual discharge in the Red River at Fargo, North Dakota also reflected this precipitation trend. Red River discharge peaked high

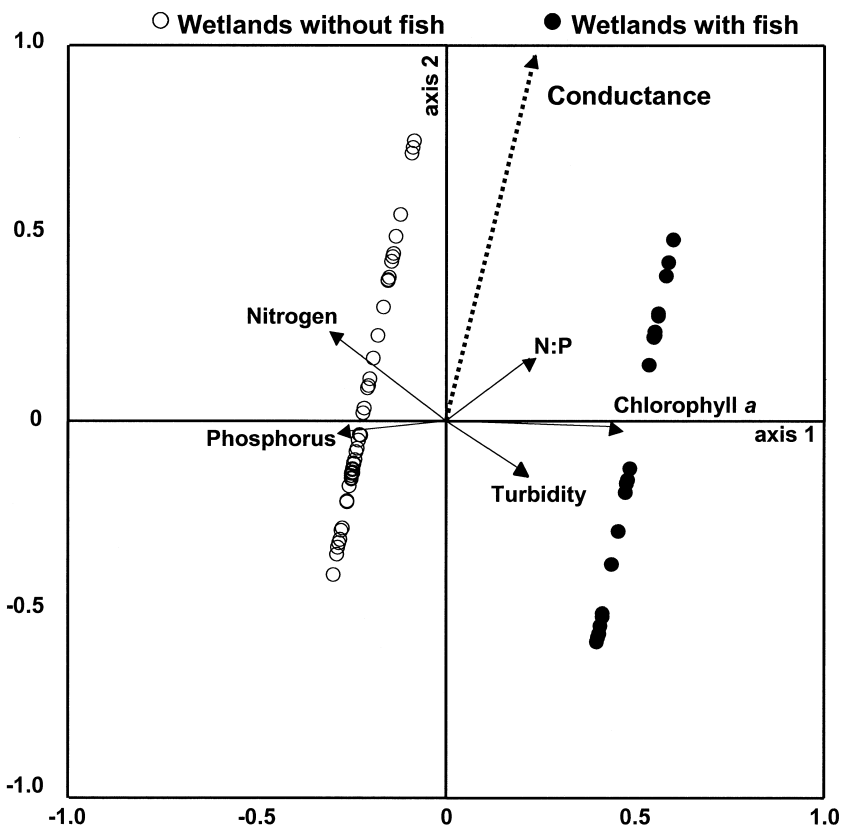

Figure 6. Partial redundancy analysis triplot for the waterquality data from the ND sites based on fish (presence/absence) and specific conductance as explanatory variables and time as a covariable. Water-quality vectors and the specific conductance vector point in the direction of increasing values among sites. Axis 1 and 2 explained $7.0 \%$ and $0.5 \%$ of the variance in water-quality characteristics, respectively.

consistently during 1993-2000. High peak discharge also occurred during 1882 and 1896, but consistent, elevated peak discharge was more evident from 1993 to 2000 (Figure 7D).

Cluster analysis based on landscape moisture data (annual precipitation [regional and local], PDSI, and peak discharge in the Red River) recorded from 19502000 indicated that seven of the last eight years grouped together along with seven earlier years; this group was wetter than combinations comprised of 37 other years during the period 1950-2000 $(\mathrm{P}<0.001$; Figure 8). Continuity of moisture on the landscape may be more important for wetland communities than annual wetness or extent of departure from normal precipitation in any given year. The magnitudes of annual precipitation, PDSI, and Red River discharge described here for the period 1991-2000 are generally within historical ranges. Yet, these data reflect a relatively uninterrupted sequence of approximately 10 years characterized by extremely moist conditions along the eastern limits of the PPR.

\section{DISCUSSION}

Food Web Effects in Wetlands

Presence of fathead minnows was associated with significant variance in abundance of zooplankton, nek- 
A

Minnesota, Division I

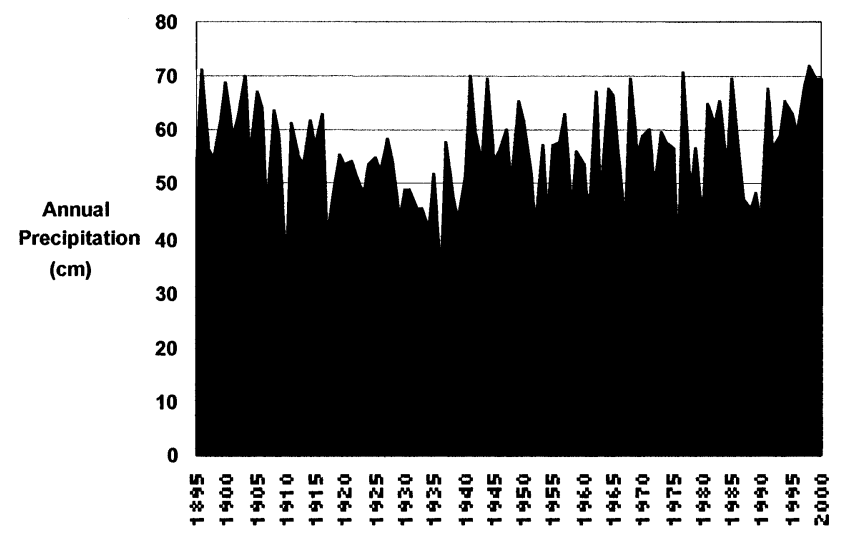

C Minnesota, Division I

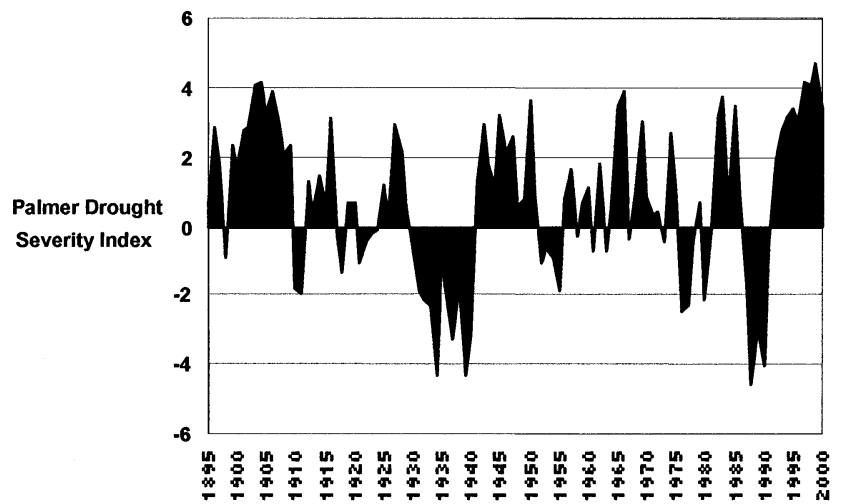

B

Fergus Falls, Minnesota

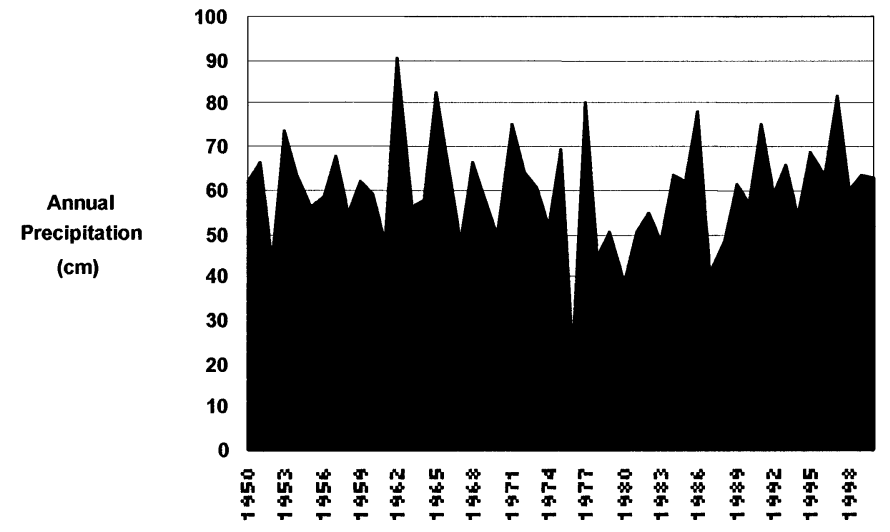

Red River at Fargo, ND

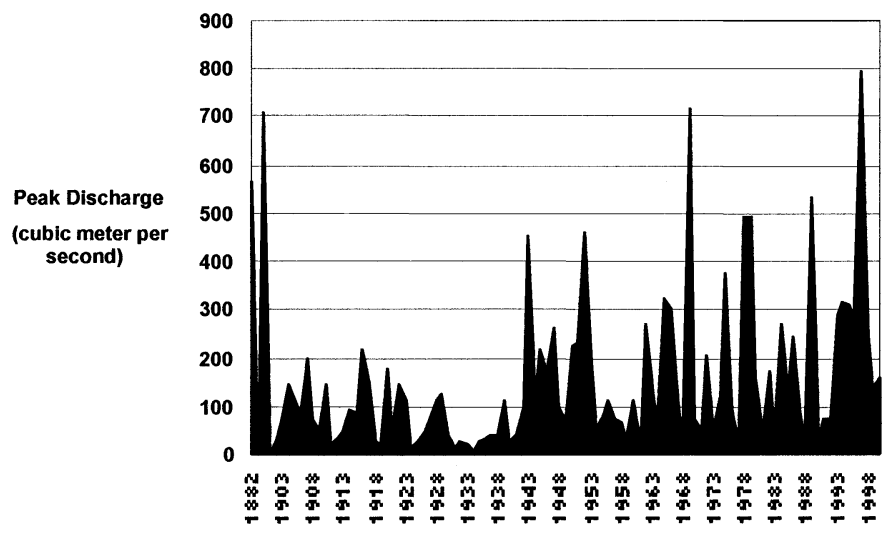

Figure 7. Summary of landscape moisture characteristics along the eastern extent of the Prairie Pothole Region. Panel A shows annual precipitation totals for Minnesota Division I from 1985 to 2000, panel B annual precipitation for Fergus Falls, MN, from 1950 to 2000, panel C the Palmer Drought Index for MN Division I from 1895 to 2000, and panel D annual peak discharge in Red River at Fargo, North Dakota from 1882 to 2000.

tonic, benthic invertebrates, and several water-quality features in our study wetlands. Jeppeson et al. (1997) suggested that effects of fish on zooplankton, phytoplankton, and water transparency are especially pronounced in shallow waters because 1) planktivorous fish densities remain high year-round due to availability of benthic prey, 2) fish populations may be maintained by benthic organisms but opportunistically consume zooplankton when they are available, and 3) zooplankton are highly vulnerable to planktivorous fish owing to lack of depth refuge.

Our wetland analysis is unique because we simultaneously compared relative influences of biotic and abiotic variables as determinants of wetland characteristics. Presence of fathead minnows, our single surrogate source of biological variability, explained far better than did specific conductance (an abiotic analogue) observed patterns in aquatic invertebrates, TP, TN, N:
$\mathrm{P}$ ratios, chlorophyll $a$, and water clarity. This finding is consistent with predictions of Wellborn et al. (1996), who suggested that transition among structuring mechanisms best accounts for aquatic community variability along a gradient of habitat permanence. Extension of the Wellborn model predicts that influence of biotic interactions (and fish predation) is amplified with increasing habitat permanence. Thus, it is not surprising that our data reflect strong influence of biotic interactions relative to physical features (of basins or adjacent landscapes), at least over short time periods.

The strong influence of fathead minnows in our wetlands is consistent with results of previous regional studies (Hanson and Butler 1994, Hanson and Riggs 1995, Zimmer 2000, 2001a,b, 2002, 2003a) also reporting strong, food-web-mediated influences of fish in shallow lakes and prairie wetlands. Specific reasons for the functional importance of fathead minnows in 
Information Remaining
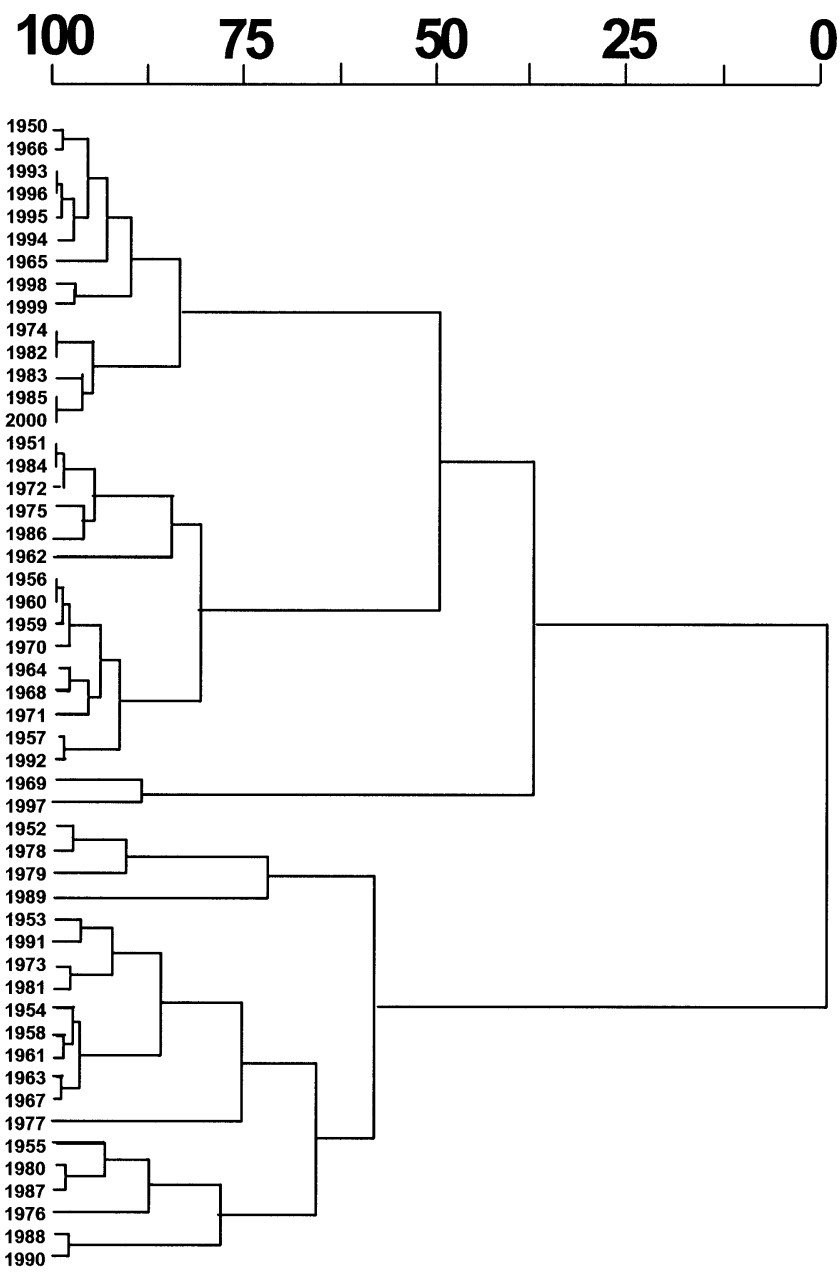

Figure 8. Results of cluster analysis of landscape moisture data (annual precipitation for MN Division I, annual precipitation at Fergus Falls, MN, the Palmer Drought Severity Index for MN Division I, and peak annual discharge in Red River at Fargo, ND) from the eastern portion Prairie Pothole Region during 1950 to 2000. MRPP tests indicated that the group of 14 years (at top), which included seven years from 1993 to 2000, was significantly wetter than other combinations of years during the half-century $(\mathrm{P}<0.001)$.

prairie wetlands are numerous. Fathead minnows use both particle- and filter-feeding strategies (Hambright and Hall 1992), thus consuming a wide variety of aquatic invertebrates. Fathead minnow populations show rapid growth, are highly productive, achieve high densities, and are often dominated by YOY fish (Payer and Scalet 1978, Zimmer et al. 2001b). Predation on invertebrates by YOY fish is especially important in lakes (Hewett and Stewart 1989, Luecke et al. 1990), and a similar influence in wetlands is not surprising. Finally, fathead minnows are facultative invertebrate predators, typically foraging on inverte- brates (Held and Peterka 1974) but also consuming periphyton and detritus (Litvak and Hansell 1990, Price et al. 1991). Consumption of detritus probably weakens the link between abundance of invertebrates and minnows (Polis and Strong 1996), further contributing to high minnow densities and strong, sustained predation pressure on aquatic invertebrates. Previous work also indicates that fathead minnows influence abundance of both submerged macrophytes and larval salamanders in PPR wetlands (Zimmer et al. 2002, 2003b).

Regional Gradients, Anthropogenic Activity, and Precipitation Dynamics: Implications for Fish

Increasing precipitation along a west-east gradient (Winter 1989) favors longer hydroperiods, greater water depths, and increased surface connectivity for many wetlands in the eastern portion of the PPR. These hydrologic characteristics, along with relatively uniform topography, all increase the likelihood that individual wetlands will merge intermittently with adjacent waters (Leibowitz and Vining 2003). They also help explain why wetlands along eastern and southern reaches of the PPR concentrate fewer solutes than those in more arid northern and western regions, a trend reflected in decreasing specific conductance of wetland waters along a northwest-southeast gradient (LaBaugh 1989). This natural moisture gradient favors survival and dispersal of wetland fish populations throughout eastern portions of the PPR.

Natural regional patterns have been accentuated by anthropogenic influences. Since 1900, alterations to this landscape have been intense, and efforts continue to increase agricultural production (Dahl 1990, Prince 1997). Approximately 3.6 million ha of PPR wetlands have been drained in Minnesota alone, most converted to agriculture (Minnesota Wetland Conservation Plan 1997). Temporary and seasonal wetlands were most easily converted; thus, drainage shifted the distribution of remaining wetland types (Miller and Nudds 1996), increasing the relative proportion of deeper, more permanent basins likely to sustain fish. Surface ditching to facilitate drainage is widespread (Prince 1997) and provides new migration corridors among remaining wetlands. Elimination of native grasses and other natural vegetation increases intermittent runoff (Euliss and Mushet 1996), possibly favoring increased immigration for wetland fish populations in agricultural landscapes.

Prairie wetlands also respond dramatically to precipitation cycles typical of the region. Drier-than-average conditions following periods of wetter years generate pronounced wet/dry oscillations with a periodicity of approximately 10-20 years (Duvick and 


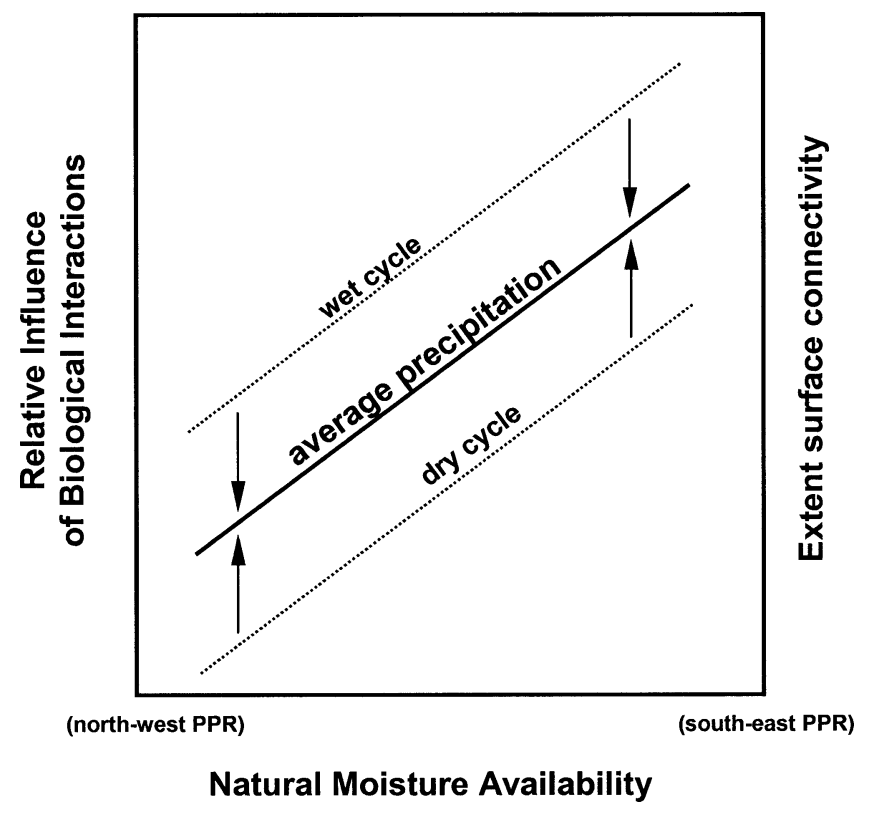

Figure 9. Conceptual model to illustrate relationships among relative magnitude of biotic interactions, landscape characteristics, and climate in prairie wetlands. We hypothesize that potential influences of biotic constraints will increase in association with increasing moisture availability and surface connectivity. We also predict that precipitation extremes will mediate increased and decreased biotic influences with wet and dry cycles, respectively, but will fluctuate along a long-term average (as indicated by arrows).

Blasing 1981, Karl and Koscielny 1982, Diaz 1983, Johnson et al. 2004). These cycles have profound but usually short-term influences on density, diversity, and community structure of wetland invertebrates (Bataille and Baldassarree 1993, Euliss et al. 1999, Hershey et al. 1999). Our analysis of historical data indicated that precipitation fluctuations of greater amplitude also occur here. Along the eastern extent of the PPR, moisture availability was consistently greater during the period of 1993-2000 than during most of the previous 90 years. Data summarized by Winter and Rosenberry (1998) indicated that the end of the $20^{\text {th }}$ century may have been the wettest period during the past 130 or even 500 years in east-central North Dakota. Highmoisture episodes have potential to influence prairie wetland communities by increasing wetland depth, hydroperiods, and surface connectivity (Leibowitz and Vining 2003, Johnson et al. 2004). Important variation in wetland communities is induced by precipitation extremes, natural moisture gradients, and surface connectivity, and we hypothesize that some of this variability results from fish predation and other biotic interactions (Figure 9). In our specific example, we observed responses to fish in wetlands along the eastern margins of the PPR. We expect less influence of fish and food-web-mediated interactions during extreme drought, with greater isolation, and in landscape settings where physical-chemical characteristics have a stronger influence on wetland community structure (Figure 9).

Significance of Biotic Constraints: The Need For Broader Paradigms

Euliss et al. (2004) suggested that influences of landscape, ground water, and moisture availability establish physical and chemical boundaries for prairie wetland characteristics and communities. This and previous accounts have clarified roles of geology, hydrology, and climate as major determinants of wetland community structure throughout the PPR (Kantrud et al. 1989a,b, Swanson and Duebbert 1989, Winter 1989, Euliss et al. 1999). Our data from semi-permanent and permanent wetlands illustrate potential influences of biotic interactions within physical and chemical limits imposed by climate and geomorphic setting. We believe that the specific roles of wetland fishes and the broader consequences of species interactions and other biotic constraints are not yet sufficiently integrated in major paradigms used to explain community patterns and characteristics of prairie wetlands. Data presented here highlighted roles of planktivorous fish. However, other biotic interactions including competition, predation by amphibians, birds, and invertebrates, community succession, and distribution of pathogenic organisms also may influence prairie wetland characteristics and communities, even in landscapes where wetlands do not support fish. A curious finding in our data was that fish presence was associated with far more variance in wetland characteristics in $\mathrm{MN}$ relative to ND sites. This would be expected if biotic interactions exert greater influence in landscapes with increasing precipitation and surface connectivity (Figure 9). It is also possible that these differences may reflect variation in sampling protocols and analyses between $\mathrm{MN}$ and ND sites.

We believe that researchers and managers should consider implications of trophic interactions, influences of wetland fishes and amphibians, and other biological factors in development of study designs and management protocols for prairie wetlands. We hypothesize that 1) ecological influences of fish in wetlands increase from northwest to southeast across the PPR, 2) proportion of wetlands with fish fluctuates with precipitation cycles, and 3) wetland fish occur in a greater proportion of wetlands in regions where surface connectivity (and anthropogenic alterations) of landscapes are more extensive. We encourage investigators to test these notions and to explore models that better integrate biotic influences with hydrogeomorphic condi- 
tions in their efforts to explain community patterns and variability in prairie wetlands.

\section{ACKNOWLEDGMENTS}

Funding for this work was provided by the Division of Wildlife, MDNR, the USGS State Partnership Program, the Regional Grants Program of the National Institute for Water Resources, administered by the USGS, the North Dakota Water Resources Research Institute, the U. S. Environmental Protection Agency through the North Dakota Department of Health, North Dakota EPSCoR, and the Gaylord and Dorothy Donnelly Foundation and Ducks Unlimited, Inc. through the Institute for Wetland and Waterfowl Research. K. Zimmer acknowledges the Department of Ecology, Evolution and Behavior at the University of Minnesota for support of this work. Extensive logistical support was provided by the U.S. Fish and Wildlife Service Wetland District Offices in Fergus Falls and Detroit Lakes, and by D. Anderson and the Douglas County Land Corporation, Evansville, MN. T. Anderson, M. Falk, T. Krabbenhoft, L. Laurich, J. Leonhart, C. Melaas, A. Mullens, M. Muscha, T. Noraker, F. Ossman, and $\mathrm{C}$. Vnuk provided valuable assistance in the field and lab. This manuscript was improved considerably by comments of D. M. Mushet, R. R. Cox, Jr., and M. Sovada. We dedicate this paper to R. T. (Todd) Eberhardt, former leader of the Wetland Wildlife Populations \& Research Group, MDNR, who nurtured this research and was passionate about wetlands. Todd died on 15 October 2002 following a long battle with cancer.

\section{LITERATURE CITED}

APHA. 1992. Standard Methods for the Examination of Water and Wastewater, $18^{\text {th }}$ edition. American Public Health Association, Washington, DC, USA

Arndt, J. L. and J. L. Richardson. 1988. Hydrology, salinity and hydric soil development in a North Dakota prairie-pothole wetland system. Wetlands 8:93-108.

Bataille, K. J. and G. A. Baldassarre. 1993. Distribution and abundance of aquatic macroinvertebrates following drought in three prairie pothole wetlands. Wetlands 13:260-269.

Biondini, M. E., P. W. Mielke, and K. J. Berry. 1988. Data-dependent permutation techniques for the analysis of ecological data. Vegetatio 75:161-168.

Dahl, T. E. 1990. Wetland losses in the United States 1780's to 1980's. U.S. Fish and Wildlife Service, Washington, DC, USA.

Diaz, H. F. 1983. Some aspects of major dry and wet periods in the contiguous United States, 1895-1981. Journal of Climate and Applied Meteorology 22:3-16.

Duvick, D. N. and T. J. Blasing. 1981. A dendroclimatic reconstruction of annual precipitations amounts in Iowa since 1680. Water Resources Research 17:1183-1189.

Euliss, N. H., Jr. and D. M. Mushet. 1996. Water-level fluctuation in wetlands as a function of landscape condition in the prairie pothole region. Wetlands 16:587-593.

Euliss, N. H., Jr., G. A. Swanson, J. W. LaBaugh, R. D. Nelson, T. C. Winter, D. O. Rosenberry, and D. M. Mushet. 2004. The wet- land continuum: a conceptual framework for interpreting biological studies in the prairie pothole region. Wetlands 24:448-458.

Euliss, N. H., Jr., D. A. Wrubleski, and D. M. Mushet. 1999. Wetlands of the Prairie Pothole Region: invertebrate species composition, ecology, and management. p. 471-514. In D. P. Batzer, R. D. Rader, and S. A. Wissinger (eds.) Invertebrates in Freshwater Wetlands of North America: Ecology and Management, John Wiley \& Sons, Inc., New York, NY, USA.

Hambright, K. D. and R. O. Hall. 1992. Differential zooplankton feeding behaviors, selectivities, and community impacts of two planktivorous fishes. Environmental Biology of Fishes 35:401411.

Hanson, M. A. and M. G. Butler. 1994. Responses of plankton, turbidity, and macrophytes to biomanipulation in a shallow prairie lake. Canadian Journal of Fisheries and Aquatic Sciences 51: $1180-1187$.

Hanson, M. A. and M. R. Riggs. 1995. Effects of fish predation on wetland invertebrates: a comparison of wetlands with and without fathead minnows. Wetlands 15:167-175.

Held, J. W. and J. J. Peterka. 1974. Age, growth, and food habits of the fathead minnow, Pimephales promelas, in North Dakota saline lakes. Transactions of the American Fisheries Society 103: $743-757$.

Hershey, A. E., L. Shannon, G. J. Niemi, A. R. Lima, and R. R. Regal. 1999. Prairie wetlands of south-central Minnesota: Effects of drought on invertebrate communities. p. 515-541. In D. P. Batzer, R. D. Rader, and S. A. Wissinger (eds.) Invertebrates in Freshwater Wetlands of North America: Ecology and Management, John Wiley \& Sons, Inc., New York, NY, USA.

Herwig, B. R., M. A. Hanson, J. R. Reed, B. G. Parsons, A. J. Potthoff, M. C. Ward, K. D. Zimmer, M. G. Butler, D. W. Willis, and V. A. Snook. 2004. Walleye stocking as a tool to suppress fathead minnows and improve habitat quality in semipermanent and permanent wetlands in the prairie pothole region of Minnesota. Section of Fisheries and Wildlife, Minnesota Department of Natural Resources, St. Paul, MN, USA. Special Publication 159.

Hewett, S. W. and D. J. Stewart. 1989. Zooplanktivory by alewives in Lake Michigan: Ontogenetic, seasonal and historical patterns. Transactions of the American Fisheries Society 118:581-596.

Hbáček, J., M. Dvořákova, V. Kořínek, and L. Procházková. 1961. Demonstration of the effect of the fish stock on the species composition of zooplankton and the intensity of metabolism of the whole plankton association. Verhandlungen Internatinal Vereinigung Limnologie 14:192-195.

Hubert, W. A. 1983. Passive capture techniques. p. 95-122. In L. A. Nielson and D. L. Johnson. (eds.) Fisheries Techniques. Southern Printing Co., Inc., Blacksburg, VA, USA.

Jeppesen, E., J. P. Jensen, M. Sondergaard, T. Lauridsen, L. J. Pedersen, and L. Jensen. 1997. Top-Down control in freshwater lakes: the role of nutrient state, submerged macrophytes and water depth. Hydrobiologia 342/343:151-164.

Johnson, W. C., S. E. Boettcher, K. A. Poinai, and G. R. Guntenspergen. 2004. Influences of weather extremes on the water levels of glaciated prairie wetlands. Wetlands 24:385-398.

Kantrud, H. A., G. L. Krapu, and G. A. Swanson. 1989a. Prairie basin wetlands of the Dakotas: a community profile. U.S. Fish and Wildlife Service, Washington, DC, USA. Biological Report 85(7.28).

Kantrud, H. A., B. Millar, and A. G. van der Valk. 1989b. Vegetation of wetlands of the Prairie Pothole Region. p. 132-187. In A. G. van der Valk (ed.) Northern Prairie Wetlands. Iowa State University Press, Ames, IA, USA.

Karl, T. R. and A. J. Koscielny. 1982. Drought in the United States: 1895-1981. Journal of Climatology 2:313-329.

LaBaugh, J. W. 1989. Chemical characteristics of water in northern prairie wetlands. p. 132-187. In A. G. van der Valk (ed.) Northern Prairie Wetlands. Iowa State University Press, Ames, IA, USA.

LaBaugh, J. W., T. C. Winter, and D. O. Rosenberry. 1998. Hydrologic functions of prairie wetlands. Great Plains Research 8:1737.

LaBaugh, J. W., T. C. Winter, G. A. Swanson, D. O. Rosenberry, R. D. Nelson, and N. H. Euliss, Jr. 1996. Changes in atmospheric 
circulation patterns affect midcontinent wetlands sensitive to climate. Limnology and Oceanography 41:864-870.

Leibowitz, S. G. and K. C. Vining. 2003. Temporal connectivity in a prairie pothole complex. Wetlands 23:13-25.

Litvak, M. K. and R. I. Hansell. 1990. Investigation of food habit and niche relationships in a cyprinid community. Canadian Journal of Zoology 68:1873-1879.

Ludwig, J. A. and J. F. Reynolds. 1988. Statistical Ecology: a Primer on Methods and Computing. John Wiley and Sons, New York, NY, USA.

Luecke, C., M. J. Vanni, J. J. Magnuson, J. F. Kitchell, and P. J. Jacobson. 1990. Seasonal regulation of Daphnia populations by planktivorous fish: implications for the clearwater phase. Limnology and Oceanography 35:1718-1733.

Luoma, J. R. 1985. Twilight in pothole country. Audubon 87:6884.

Magnuson, J. J., W. M. Tonn, A. Banerjee, J. Toivonen, O. Sanchez, and R. Martti. 1998. Isolation vs. extinction in the assembly of fishes in small northern lakes. Ecology 79:2941-2856.

McCune, B. and J. B. Grace. 2002. Analysis of Ecological Communities. MjM Software Design, Gleneden Beach, OR, USA.

MCCune, B. and M. J. Mefford. 1999. PC-ORD. Multivariate Analysis of Ecological Data, Version 4. MjM Software Design, Gleneden Beach, OR, USA.

Merritt, R. W. and K. W. Cummins. 1996. An Introduction to the Aquatic Insects of North America. $3^{\text {rd }}$ edition. Kendall/Hunt Publishing Company, Dubuque, IA, USA.

Miller, M. W. and T. D. Nudds. 1996. Prairie landscape change and flooding in the Mississippi River Valley. Conservation Biology $10: 847-853$

Minnesota Department of Natural Resources. 1997. Minnesota Wetlands Conservation Plan. Minnesota DNR, St. Paul, MN, USA.

Minnesota Department of Natural Resources. 2001. Climate's impact upon water availability in Minnesota. Minnesota DNR, Division of Waters, Climatology Program. Minnesota DNR, St. Paul, MN, USA.

Murkin, H. R. 1989. The basis for food chains in prairie wetlands. p. 316-338. In A. G. van der Valk (ed.) Northern Prairie Wetlands. Iowa State University Press, Ames, IA, USA.

Murkin, H. R., P. G. Abbot, and J. A. Kadlec. 1983. A comparison of activity traps and sweep nets for sampling nektonic invertebrates in wetlands. Freshwater Invertebrate Biology 2:99-106.

Palmer, W. C. 1965. Meteorological drought. U.S. Weather Bureau, Washington, DC, USA. Research Paper No. 45.

Payer, R. D. and C. G. Scalet. 1978. Population and production estimates of fathead minnows in a South Dakota prairie wetland. Progressive Fish-Culturist 40:63-66.

Pennak, R. W. 1989. Fresh-water Invertebrates of the United States: Protozoa to Mollusca. $3^{\text {rd }}$ edition. John Wiley and Sons, New York, NY, USA.

Polis, G. A. and D. R. Strong. 1996. Food web complexity and community dynamics. American Naturalist 147:813-846.

Price, C. J., W. M. Tonn, and C. A. Paszkowski. 1991. Instraspecific patterns of resource use by fathead minnows in a small boreal lake. Canadian Journal of Zoology 69:2109-2115.

Prince, H. 1997. Wetlands of the American Midwest. University of Chicago Press, Chicago, IL, USA.

Rahel, F. J. 1984. Factors structuring fish assemblages along a bog successional gradient. Ecology 65:1276-1289.

Rice, W. R. 1990. A consensus combined P-value test and the family-wide significance of component tests. Biometrics 46:303-308.

Richardson, J. L. and J. L. Arndt. 1989. What use prairie potholes? Journal of Soil and Water Conservation 44:196-198.

Scheffer, M. 1998. Ecology of Shallow Lakes. Chapman and Hall, London, UK.

Stewart, R. E. and H. A. Kantrud. 1971. Classification of natural ponds and lakes in the glaciated prairie region. U.S. Fish and Wildlife Service, Washington, DC, USA. Resource Publication 92.
Swanson, G. A. 1978. A plankton sampling device for shallow wetlands. Journal of Wildlife Management 42:670-672.

Swanson, G. A. and H. A. Duebbert H. 1989. Wetland habitats of waterfowl in the prairie pothole region. p. 228-267. In A. G. van der Valk (ed.) Northern Prairie Wetlands. Iowa State University Press, Ames, IA, USA.

Swanson, G. A., T. C. Winter, V. A. Adomaitis, and J. W. LaBaugh. 1988. Chemical characteristics of prairie lakes in south-central North Dakota: their potential for influencing use by fish and wildlife. U.S. Fish and Wildlife Service, Washington, DC, USA. Technical Report 18

ter Braak, C. J. and J. Wiertz. 1994. On the statistical analysis of vegetation change: a wetland affected by water extraction and soil acidification. Journal of Vegetation Science 5:361-372.

ter Braak, C. J. 1995. Ordination. p. 91-173. In R. H. Johnman, C. J. ter Braak, and O. F. van Tongeren (eds.) Data Analysis in Community and Landscape Ecology. Cambridge University Press, Cambridge, UK.

ter Braak, C. J. and P. Smilauer. 1998. Canoco Reference Manual and User's Guide to Canoco for Windows: Software for Canonical Community Ordination (version 4). Microcomputer Power, Ithaca, NY, USA

Tonn, W. M. and J. J. Magnuson. 1982. Patterns in the species composition and richness of fish assemblages in northern Wisconsin lakes. Ecology 63:1149-1166.

Van Wijngaarden, R. P., P. J. Van den Brink, J. H. Oude Voshaar, and P. Leeuwangh. 1995. Ordination techniques for analysing response of biological communities to toxic stress in experimental ecosystems. Ecotoxicology 4:61-77.

Wellborn, G. A., D. K. Skelly, and E. E. Werner. 1996. Mechanisms creating community structure across a freshwater habitat gradient. Annual Reviews of Ecology and Systematics 27:337-363.

Winter, T. C. 1989. Hydrologic studies of wetlands in the northern prairie. p. 16-54. In A. G. van der Valk (ed.) Northern Prairie Wetlands. Iowa State University Press, Ames, IA, USA.

Winter, T. C. and D. O. Rosenberry. 1998. Hydrology of Prairie Pothole Wetlands during drought and deluge: a 17-year study of the Cottonwood Lake Wetland Complex in North Dakota in perspective of longer term measured and proxy hydrological records. Climate Change 40:189-209.

Winter, T. C. and M. K. Woo. 1990. Hydrology of lakes and wetlands. p. 159-187. In M. G. Wolman and H. C. Riggs (eds.) The Geology of North America, Vol. 0-1, Surface Water Hydrology. The Geological Society of America, Boulder, CO, USA.

Zimmer, K. D., M. A. Hanson, and M. G. Butler. 2000. Factors influencing invertebrate communities in prairie wetlands: a multivariate approach. Canadian Journal of Fisheries and Aquatic Sciences 57:76-85

Zimmer, K. D., M. A. Hanson, and M. G. Butler. 2001a. Effects of fathead minnow colonization and removal on a prairie wetland ecosystem. Ecosystems 4:346-357.

Zimmer, K. D., M. A. Hanson, and M. G. Butler. 2002. Effects of fathead minnows and restoration on prairie wetland ecosystems. Freshwater Biology 47:2071-2086.

Zimmer, K. D., M. A. Hanson, and M. G. Butler. 2003a. Relationships among nutrients, phytoplankton, macrophytes, and fish in prairie wetlands. Canadian Journal of Fisheries and Aquatic Sciences 60:721-730.

Zimmer, K. D., M. A. Hanson, and M. G. Butler. 2003b. Interspecies relationships, community structure, and factors influencing abundance of submerged macrophytes in prairie wetlands. Wetlands 23:717-728.

Zimmer, K. D., M. A. Hanson, M. G. Butler, and W. G. Duffy. 2001b. Influences of fathead minnows and aquatic macrophytes on nutrient partitioning and ecosystem structure in two prairie wetlands. Archiv für Hydrobiologie 150:411-433.

Manuscript received 2 December 2002; revisions received 6 July 2003, 18 March 2004, and 14 February 2005; accepted 30 May 2005 . 